\title{
CITIZEN SCIENCE DATA PREDICT HIGH POTENTIAL FOR MACROFUNGAL REFUGIA OUTSIDE PROTECTED RIPARIAN AREAS
}

Sabine Fink, Andrin Gross, Beatrice Senn-Irlet and Christoph Scheidegger

sabine.fink@wsl.ch; +41 4473928 36; Swiss Federal Institute for Forest, Snow and Landscape Research (WSL), Biodiversity and Conservation Biology, Zürcherstrasse 111, 8903 Birmensdorf, Switzerland

andrin.gross@wsl.ch; +41 4473922 75; Swiss Federal Institute for Forest, Snow and Landscape Research (WSL), Biodiversity and Conservation Biology, Zürcherstrasse 111, 8903 Birmensdorf, Switzerland

beatrice.senn@wsl.ch; +41 4473922 43; Swiss Federal Institute for Forest, Snow and Landscape Research (WSL), Biodiversity and Conservation Biology, Zürcherstrasse 111, 8903 Birmensdorf, Switzerland

christoph.scheidegger@wsl.ch; Swiss Federal Institute for Forest, Snow and Landscape Research (WSL), Biodiversity and Conservation Biology, Zürcherstrasse 111, 8903 Birmensdorf, Switzerland

\section{Corresponding author:}

Sabine Fink

sabine.fink@wsl.ch; Swiss Federal Institute for Forest, Snow and Landscape Research (WSL), Biodiversity and Conservation Biology, Zürcherstrasse 111, 8903 Birmensdorf, Switzerland phone: +41 4473928 36; fax: +41 447392215

This document is the accepted manuscript version of the following article:

Fink, S., Gross, A., Senn-Irlet, B., \& Scheidegger, C. (2021). Citizen science data predict high potential for macrofungal refugia outside protected riparian areas. Fungal Ecology,

1

49, 100981 (9 pp.). https://doi.org/10.1016/j.funeco.2020.100981

This manuscript version is made available under the CC-BY-NC-ND 4.0

license http://creativecommons.org/1icenses/by-nc-nd/4.0/ 


\title{
Research highlights
}

- Definition of target fungi for conservation and restoration of riparian areas

- Species distribution models with geological, topographic and climatic predictors

- More relative fungal records inside protected areas

- More predicted suitable habitat outside protected areas

- Application for fungal conservation and restoration projects

\begin{abstract}
Protected areas with restricted management can provide refugia for fungi, but are usually selected based on conservation strategies for flora and fauna. Despite the important role of fungi in floodplains, they are rarely considered in conservation projects. The SwissFungi records database covering all biogeographic regions in Switzerland, and consisting of 84\% citizen science data, provided a valuable basis to define fungal riparian species: $99.29 \%$ of 990 species were reported at least once from the riparian zone, while $15 \%$ of species showed a measurable riparian affinity. Species distribution modeling for 129 riparian macrofungi revealed that the predicted distribution is driven by temperature for most species. There were significantly more records per species inside compared to outside protected areas, when correcting for size differences (21\% of the area in Switzerland is protected). In contrast, the model predicted significantly more suitable habitat outside currently protected areas. Unprotected areas harbor a high potential for the creation of newly protected areas for the conservation of riparian fungi. The database information and the modelling approach provided crucial information for future monitoring and conservation projects along rivers.
\end{abstract}

\section{Keywords}

Riparian ecosystem, floodplain, fungi, species distribution models (SDM), citizen science data, protected areas, refugia, functional groups, conservation management 


\section{Introduction}

Natural riparian ecosystems are composed of a mosaic of habitats showing extreme environmental gradients, i.e. from dry to wet or from highly dynamic to stable patches (Naiman et al., 2005). This habitat diversity on a small spatial scale results in high species diversity compared to adjacent non-riparian areas (Klimo, 2001, Sabo et al., 2005). However, riparian areas and especially river floodplains are threatened. For the last two centuries, major flood prevention projects in Europe led to the loss of natural river dynamics (Nilsson et al., 2005) and a decrease of species diversity (Federal Office for the Environment, 2017).

Conservation policy states that floodplain restoration is of major importance in Europe (Moss and Monstadt, 2008). Therefore, riparian plant diversity has been widely studied (Naiman et al., 2005, Richardson et al., 2007, Catford and Jansson, 2014). Knowledge of other terrestrial floodplain organisms is limited to flagship species or restricted areas (e.g. Stockan et al., 2014). Despite their crucial role in e.g. decay processes or carbon and nutrient cycling (Boddy et al., 2008, Smith, 2009), little is known about the distribution of fungi in riparian ecosystems.

Riparian habitats harbor mainly lignicolous and terrestrial saprobes (e.g. Mihal and Blanar, 2014). The number of ectomycorrhizal symbionts is low and early stages of succession are dominated by arbuscular mycorrhizal fungi which do not produce fruit bodies (Piotrowski et al., 2008). Fungal species richness in riparian areas is correlated with floodplain forest plant species (Naiman et al., 2005) and fungal - plant co-adaptations have been shown (Sakio and Tamura, 2008, Li et al., 2010).

While a limited number of fungi are strictly dependent on a functional floodplain ecosystem, some riparian species can also colonize non-riparian habitats (Senn Irlet, 2012, Fink and Senn-Irlet, 2016, Gross et al., 2019). Protected areas with restricted management, such as national parks and nature reserves, can provide refugia for fungi (Turrini and Giovannetti, 
2012). In fragmented landscapes, riparian fungal populations in protected areas can provide sources for re-colonization of restored areas (Burnett, 2003).

Databases of citizen science data are getting more and more valuable to study the biogeography of species (Devictor et al., 2010, Ainsworth et al., 2018, Andrew et al., 2019) and the success of management and conservation efforts (Bonney et al., 2009, Dickinson et al., 2010, Tulloch et al., 2013, Aceves-Bueno et al., 2017). The contribution of volunteer mycologists is especially useful, since the detection of fruit bodies is often limited to short time periods (Purhonen et al., 2017) and is highly weather dependent (Talley et al., 2002). However, certain drawbacks of citizen science data, such as e.g. observer errors and variation in sampling effort in space and time, should not be neglected (Dickinson et al., 2010).

Ecological niche modelling linking fungal data from volunteer mycologists and habitat information provide a powerful tool to overcome some of the limitations of citizen science data. With this method, overlooked or uncolonized habitats can be detected. Species distribution models (SDM, also known as habitat or niche models) have proven to be useful for conservation planning (Guisan et al., 2013). This approach has been previously used for predicting fungal distribution for threatened (Tukiainen et al. 2017) and pathogenic species (Schatz et al. 2017), based on herbarium data (Wollan et al. 2008), and also for forecasting future distributions of fungi mainly in forest habitats (Abrego et al., 2017, Mair et al., 2017, Wicaksono et al., 2017, Mair et al., 2018).

To improve conservation measures for riparian fungi in Switzerland, this study aimed at defining floodplain dependent species based on the fungal records database SwissFungi (Gross et al., 2019) and investigating focal species'distributions in Switzerland. We identified the main predictors for species occurrence and predict core areas of species' distributions inand outside protected areas independent of the respective niche. We evaluated the need for new protected sites: If currently protected areas indeed provide refugia for riparian 
macrofungi, we expect higher species records as well as more predicted suitable habitat within these areas. For more information for management planning, we investigated differences between the distributions of functional groups of riparian macrofungi.

\section{Methods}

\section{Citizen science data}

Riparian fungal species were selected from the database SwissFungi (Gross et al., 2019), which is part of the national center for biodiversity InfoSpecies (https://www.infospecies.ch). This database hosts occurrence data obtained in monitoring projects on behalf of the Federal Office for the Environment of Switzerland and Swiss cantonal authorities (11\%), literature and herbarium records from research projects (5\%) as well as records by volunteer mycologists (84\%). All submissions were processed by trained field mycologists. The validation process included taxonomic and nomenclatural synonymisation by experts and various quality controls (e.g. date, geographical reliability, habitat, host).

\section{Riparian fungal species' identification}

Species for the current study were selected from all entries (retrieved on April 06, 2018) based on their respective occurrence in proximity to rivers, represented as a riparian zone along riverways in Switzerland. The riparian zone in this study was defined as a perimeter according to Swiss regulations (waters protection ordinance, status as of February 2, 2016), where minimal spatial requirements for the riparian corridors are dependent on the river bed width. According to law, the riparian corridor of small rivers up to $2 \mathrm{~m}$ wide require a minimum width of $11 \mathrm{~m}$. Intermediate rivers of $2-15 \mathrm{~m}$ require a riparian zone of 2.5 times the size of the river bed and an additional $7 \mathrm{~m}$ buffer zone. The riparian corridor of large rivers with a river bed $>15 \mathrm{~m}$ is individually determined. Following these regulations, we 
used 12 categories of spatial circumferences applied to a vector layer of Swiss rivers including information of the river bed width from a publication on river morphology from the Federal Office for the Environment (Baumgartner, 2009) to define the riparian zone. For small rivers of up to $2 \mathrm{~m}$, a perimeter of $5.5 \mathrm{~m}$ was added on each side, and for intermediate rivers of 2.1 - $15 \mathrm{~m}$ river bed width, a riparian zone of $22.5 \mathrm{~m}$ on each river side. For larger rivers with river beds $>15 \mathrm{~m}$ up to $900 \mathrm{~m}$ wide, we set riparian zones using 10 categories: $15.1-50 \mathrm{~m}$ river bed width: $50 \mathrm{~m}$ perimeter on each side, $50.1-100 \mathrm{~m}$ river bed width: 100 m perimeter on each side, 100.1 - 200 m river bed width: $150 \mathrm{~m}$ perimeter and an increase of the perimeter size of $50 \mathrm{~m}$ for each $100 \mathrm{~m}$ in bed width increase until the final category representing 800.1 -901 m river bed width with $500 \mathrm{~m}$ perimeter on each side. The modifications of the perimeters have been done in ArcGIS (ESRI, 2015).

We selected all species present in the database with $\geq 100$ occurrence points in Switzerland and which showed at least one presence point within the riparian zone. Additionally, only coordinates with a precision of $250 \mathrm{~m}$ or better (total uncertainty) and collection dates between 1960 and 2015 were used. Given the heterogeneity of the data origins, we calculated a base value for average river affinity across the dataset by dividing the number of occurrence points of all species within the riparian zone by the total number of occurrence points overall (total overall: 495,924; total within riparian zone: 16,228; rounded ratio value, further referred to as base value $\mathrm{B}=0.033$, compare to Appendix 1 , Table A1 and A2). To detect floodplain affine species, the same ratio was calculated for each species separately, and compared to the base value of average river affinity (value A, see Appendix 1, Table A1 and A2). Species with a ratio $\mathrm{A} / \mathrm{B} \geq 2$ times higher than the average value were considered as river affine species (values for each species see Appendix 1, Table A1 and A2). This approach avoided taking into account the area covered by the data acquiring processes. 
The selected locations of species' occurrence were transformed to a raster of $25 \times 25 \mathrm{~m}$ using the raster package in R (Hijmans and van Etten, 2012). Duplicates per raster cell were removed to avoid spatial autocorrelation (Guisan and Zimmermann, 2000). Only species with $\geq 100$ records after data cleaning were considered for modelling (see Table A1). For each species, the functional group (ectomycorrhizal species, plant parasitic species, saprobic soil species, saprobic dead wood species and other saprobic species) is given in Table A1 (information according to data base entries). We checked for areas with high species presence points and areas without any species records using the presence points rasters mentioned above.

\section{Cross-validation of the riparian species}

To retrace and validate the list of species with presence points within the riparian zone, we characterized the ecology of the species based on additional data from the database SwissFungi (Gross et al., 2019) and based on standard mycological identification handbooks (Breitenbach and Kränzlin, 1981-2005, Krieglsteiner, 2000-2010, Gminder, 2008, 2010). The following ecological data were extracted (download 24.5.2019) for each species and individual record: (i) functional group (ectomycorrhizal symbiontic vs. saprobic vs. parasitic) of species; (ii) substrate on which species is usually found; (iii) habitat classification according to Delarze and Gonseth (2015) where a species was recorded, and (iv) host choice for records of saprobic and parasitic species. Using the habitat classification data (iii), we summed the number of different habitat classes a species was assigned to as an indicator for "generalism" of a species: specialists showed records assigned to single or a few habitat classes, while generalists showed records assigned to various habitat classes. Finally, we commented on each species and gave the most probable reason why a species might have a riparian affinity (see Appendix 1, Table A3). 


\section{Ecological niche modelling}

To map the ecological niche of riparian macrofungi in Switzerland, we applied the method of species distribution modelling by calculating a habitat suitability matrix based on presence data and environmental predictor layers from Switzerland (Franklin, 2009). Geological, topographic and climate predictors were used as proxies to define the ecological niche. 21 environmental predictor layers for Switzerland with a resolution of 25 x 25 m were checked and projected in ArcGIS (ESRI, 2015). The resulting layers were checked for collinearity using Pearson correlation test in the raster package of R (Hijmans and van Etten, 2012). Layers showing collinearity $>0.75$ were excluded from the analysis, resulting in 15 layers applied (Table 1).

Species distribution modelling was done using the software maxent (Phillips et al., 2006) and the following settings: sampling of 10,000 background points and ten-fold-crossvalidation (Phillips et al., 2009). The area under the curve (AUC) of the receiver operating characteristics was used to evaluate the predictive power of the models (see Phillips et al., 2006). We calculated Boyce index and analyzed the correlation between the ratio of predicted to expected species presences using the Ecospat package in $\mathrm{R}$ (applying a sliding window, see Hirzel et al., 2006). Relative contributions of each predictor layer to the models was calculated using maxent for each species independently.

Average habitat suitability maps of ten runs with continuous probabilities were converted to binary species presence-absence maps using the equal training sensitivity and specificity logistic threshold (Liu et al., 2013) calculated in the program maxent. Cells with reported and modelled species presences were overlapped for all species and for different functional groups in R (R Core Team, 2016) to detect core species localities. 


\section{Refugia in protected areas}

First, fungal records were grouped by presence within or outside protected areas. We checked for bias by finder and date to avoid spatial autocorrelation for fungal records within protected areas (for details see Appendix 1, Table A4). Second, occurrences within protected areas were grouped by taking into account two levels of protection and management restrictions: high protection status was assigned to floodplains of national importance, Emerald areas (European network of protected habitats), Ramsar areas (protected wetland areas), fens of national importance, dry grasslands of national importance and areas belonging to the federal inventory of protected landscapes and natural monuments (see Table 1 and Appendix 1, Figure A1), since for these areas, strong management restrictions apply. Low protection status was assigned to biosphere areas, parks of national importance, reserves for waterbirds and migratory birds of international and national importance and Swiss Game reserves. These areas are registered and monitored but management is less restricted (Federal Office for the Environment, 2010, 2015, 2017). To investigate the impact of conservation areas, we used spatial explicit information in ArcGIS (ESRI, 2015) to compare species records, modelled potential species occurrences as well as localities where a majority of species occur (see above) inside and outside of currently protected areas and tested for differences using Welch t-tests in R (Welch, 1947, R Core Team, 2016).

To test if the variables "functional groups" or "conservation area" have an effect on the number of actual species records or predicted presence of species, we applied generalized linear models (GLM) in the package stats in R (R Core Team, 2016). The variable "functional groups" was based on the information on the substrate of species from the database SwissFungi. Species were assigned to 5 main functional groups: ectomycorrhizal species, plant parasitic species, saprobic soil species, saprobic dead wood species and other saprobic species (see Appendix 1, Table A3). For the variable "conservation area", we checked if 
RIPARIAN FUNGI AND DISTRIBUTION

records were within low or highly protected areas or outside (compare to Table 1). All GLM models were corrected for overdispersion applying quasilikelihood (logistic link and scale parameter $\mu$ ). 


\section{Results}

Defining species with significant affinity to riparian ecosystems

The database included 990 species with more than 100 occurrence points in Switzerland of which 983 (99.29\%) species showed occurrence points within the defined riparian corridor, which only represents $2 \%$ of the total area of Switzerland. A total of 146 species showed a strong affinity to riparian habitat with at least twice as many occurrence points within the riparian zone compared to the average value over all species (see Appendix 1, Table A2). After data cleaning (see above), 129 species were chosen for modelling (see Appendix 1, Table A2). These species represent various functional groups (ectomycorrhizal species, plant parasitic species, saprobic soil species, saprobic dead wood species and other saprobic species, see Appendix 1, Table A2), and occupy different niches and occur across Switzerland (Figure 1). Literature on species' ecology confirmed affinity to riparian ecosystems for 107 of the identified 129 species in this study (83\%, see Appendix 1, Table A3, e.g. information on saprobic or symbiotic lifestyle on riparian woody and herbaceous plants or substrate).

\section{Species distribution modelling}

For each of the 129 species, models were performed individually. Modelling results for only 104 species showed high AUC values (>0.70), indicating good prediction accuracy (see Appendix 1, Table A1 and compare to Manel et al., 2001). Model evaluations showed high correlations $>0.90$ of the ratio of predicted to expected presence points and habitat suitability (see Appendix 1, Table A1, Appendix 2 and compare to Hirzel et al., 2006).

The predictor with the highest average model prediction contribution over 10 runs was the mean annual temperature layer for all species except for four species: Cortinarius fraudulosus (highest contributing layer: water-holding capacity of soil), Diatrype bullata (slope), 
Entoloma incanum (mean annual precipitation) and Geopora arenicola (calcareous content of the bedrock and surface material, see Appendix 1, Table A5).

Modelled habitat suitability maps for individual species and binary maps with predicted species occurrences and absences are given in the Appendix 3. $26.11 \%$ of all cells in Switzerland showed no predicted occurrence for any species. All 104 species were never predicted to occur together in one cell. Predicted species presence for a maximum of 103 species was found in 69 cells $(0.0001 \%$ of all cells). All catchments showed cells where many species were predicted to occur (Figure 2). Predicted distributions of species belonging to different functional groups showed minor differences between catchments (e.g. Ticino, see Figure 3).

\section{Refugia in protected areas}

The protected areas covered $21.09 \%$ of all raster cells representing Switzerland in the model. $18.22 \%$ of all cells are under high protection (see methods) and only $5.24 \%$ under low protection. The data set used for the study showed that for a majority of records, individual finders reported more species outside a protected area than inside on a unique date $(79.3 \%)$, while the opposite was true for only $17.4 \%$ (more records inside than outside protected areas) of the cases. In the remaining $3.3 \%$ of the recorded data, each individual volunteer mycologist noted equal numbers of species inside and outside protected areas on a single day (for details, see Appendix 1, Table A4).

Pairwise t-tests comparing species presence within and outside all protected areas revealed significant differences (after correction for area size differences, Welch t-test, $\mathrm{t}=2.9173$, $\mathrm{p}<0.01)$, as $73 \%$ of the species showed a higher presence within areas under protection after correction for size of the area. $95 \%$ of all species show more presence points within areas with high protection (after correction for area size, Welch $\mathrm{t}$-test, $\mathrm{t}=4.3465, \mathrm{p}<0.01$ ). For areas 
with low protection, there was no significant difference between species records inside and outside low protected areas (after correction for area size, Welch $\mathrm{t}$-test, $\mathrm{t}=-1.315, \mathrm{p}=0.19$ ). The modelled species occurrence revealed that significantly more cells remained unoccupied by fungal species compared to occupied cells (Welch t-test, $\mathrm{t}=-114.4, \mathrm{p}<0.01$ ). Individual species were predicted to occupy 3.8 - $34.9 \%$ (median: $19.3 \%$ ) of all raster cells. Significantly more predicted occupied cells were found outside all protected areas for a majority of species (corrected for size differences, $98 \%$, Welch t-test, $\mathrm{t}=-12.282, \mathrm{p}<0.01$ ); the same was found for highly protected areas (corrected for size differences, $100 \%$, Welch ttest, $\mathrm{t}=-19.074, \mathrm{p}<0.01$ ) and areas with low protection status (corrected for size differences, $100 \%$, Welch t-test, $\mathrm{t}=-47.95, \mathrm{p}<0.01)$

Results of GLM models suggested a significant influence of both variables "functional group" and "conservation area" on the actual and predicted occurrence of fungal species in Switzerland (Table 2). The effect was only significant for the functional groups with higher numbers of species, whereas it was never significant for parasites and other saprobes, probably due to the low number of species (Table 2). While the significant effect of saprobes on wood, saprobes on soil and ectomycorrhiza on the distribution of presence points remained when only highly protected or low protected areas were considered, this effect got lost for saprobes when considering modelled species occurrence. 


\section{Discussion}

\section{Citizen science data to identify riparian macrofungi}

Defining riparian species is difficult, as floodplains display a high habitat and niche diversity (Naiman et al., 2005, Ellenberg, 2010). Therefore, expert knowledge or information of various studies are usually used to identify and define riparian species (Schnitzler-Lenoble and Carbiener, 2007, Delarze and Gonseth, 2015). Herein, a purely spatially explicit occurrence data based approach was used to identify riparian species for which the citizen science database of SwissFungi provided a valuable basis. In Switzerland, riparian areas occur in different biogeographic regions and at various altitudes (Auenberatungsstelle 2001-2008, Lauber 2018). A remarkably high number of species (>99\%) showed presence points within the riparian corridor. This interesting result has direct conservation implication since it shows that most fungal species are affected by river revitalization projects.

Around $15 \%$ of all species studied revealed a significant affinity to the riparian zone. Our method is supported by ecological data and literature (Breitenbach and Kränzlin, 1981-2005, Krieglsteiner, 2000-2010, Gminder, 2008, 2010) showing obvious reason for the bond to riparia for most of these species (e.g. saprobic or symbiotic lifestyle on typical riparian plant species such as Alnus, Salix, Populus, Fraxinus).

For certain species, an obvious reason for river affinity could not be identified, indicating that the applied procedure also recognized species that were not considered riparian species so far. Species relying to a large extent on non-typical riparian host plants such as Picea abies (e.g. Mycena strobilicola, Gloeophyllum abietinum, Cinereomyces lindbladii, Baeospora myriadophylla), Fagus sylvatica (e.g. Gymnopus brassicolens, Brunnipila fuscescens) or Larix ssp. (e.g. Lentinus lepideus) were not expected to be affiliated to riparia. Artifacts due to sampling biases or e.g. plantations of trees close to rivers cannot be ruled out. The procedure 
to identify riparian species is not biased by region, catchment or other assumptions of single site studies, given that samples originated from all over Switzerland representing different biogeographic regions and river catchments.

\section{Predicted distribution for riparian macrofungi}

Species distribution modelling for riparian macrofungi revealed that predicted species occurrence is driven by temperature for most species. This pattern within Switzerland is similar to results of a study at the European scale (Andrew et al., 2019). Temperature is usually also a major driver for riparian plant distribution (Ikeda et al., 2014, Fink and Scheidegger, 2018). Still, a few species' occurences were mainly associated with other environmental variables, which were explained by the species' ecology: the water-holding capacity was the main factor for Cortinarius fraudulosus, an ectomycorrhizal species of Norway spruce mainly occurring on calcareous gravel with low water-holding capacity (Gminder, 2010). For the Salix-specific wood degrading species Diatrype bullata, slope was the main factor, in accordance with the pioneer role of its host Salix sp. on land slides. For Geopora arenicola, often found on sand banks along rivers, the calcareous content of the bedrock and surface material was the main predictor. Finally, the mean annual precipitation was the main factor explaining the occurrence of Entoloma incanum, a species for which the ecological knowledge is still limited. Therefore, the models and the respective maps for suitable habitat help to identify potential future sampling sites for Entoloma incanum.

Predicted species distribution revealed that the main river catchment providing habitats for riparian macrofungi is the Rhine catchment, as many species display predicted distributions along rivers on the Central Plateau (e.g. Aare in the Rhine tributary, see Figure 2). This matches the clustering of plant species in this region (Welten et al., 1982), on which many wood riparian fungi rely on. Other catchments, such as e.g. Ticino, show small differences between functional groups in respect to the width and the quality of the area of the predicted 
habitats (Figure 3). Management planning at the catchment level as well as at river sites profit from spatially explicit modelling outputs: e.g. suitable sites identified by the models can be supplied with e.g. more dead wood or sediments to promote fungal growth. Additionally, the predicted species' distribution maps can also be used as a basis for future field studies.

Although all species were predicted to be widely distributed across Switzerland, no cell was identified to be suitable habitat for the presence of all species studied here. The cell size of $25 \times 25 \mathrm{~m}$ was too small for providing a core habitat for all riparian species. As species of different functional groups have individual niches, also temperature, as the joint main driver for the presences-absence pattern, showed some differences between single species. Some cells were detected with predicted occurrence for many species (up to 103 out of 104). These areas might be hotspots for species' occurrence and should be conserved, as they provide general niche characteristics which apply to many fungal species and could form sanctuaries for source populations for re-colonizations of restored areas.

\section{Refugial areas for macrofungi?}

Although only a fifth of the area of Switzerland is protected (21.09\%), a higher relative number of riparian species presence points in the database was found within protected areas, underlining their importance as sanctuaries for macrofungi. This is remarkable, given that no specific refugia for riparian fungi have been defined yet, despite many fungal species being considered as priority species for conservation within Switzerland (Federal Office for the Environment, 2011). Since the majority of predicted suitable habitat for all the selected fungal species lies outside the currently conserved areas, we argue that new fungal refugia are needed.

Future landscape and conservation planning needs to take into account groups of organisms other than plants and animals, although they might profit as well from newly formed 
sanctuaries outside current conserved areas. Lack of connectivity between habitats or shifts in habitat suitability were predicted for other riparian species (see in D'Amen et al., 2011). Modelled species distribution can form a basis for fungal refugia planning by identifying suitable sites for management restrictions along tributaries. Conservation and management strategies should focus on functional groups, as their modelled presence was significantly different in protected areas. Specific niche requirements should be based on known species' ecology (e.g. sandy soils for saprobic species such as Geopora arenicola, Geastrum triplex and Melastiza chateri). The presented modelling approach can reveal potential sites for field studies and monitoring, especially if ecological knowledge is limited for certain functional groups.

\section{Limitations of modelling approach}

For modelling, data bases including citizen science data are widely used at various geographic scales (see in Bonney et al., 2009, Dickinson et al., 2010, Elith et al., 2010). Species distribution modelling has proven useful in conservation decision making (Guisan et al., 2013). Still, the scale of the modelling approach has to be chosen wisely, to provide sufficient resolution for conservation action (Elith and Leathwick, 2009). In our case, the $25 \mathrm{x} 25 \mathrm{~m}$ grid was the best choice given that predictor layers were available in high resolution and as conservation management usually occurs at local scale (Darby and Sear, 2008).

Species distribution modelling outcome and precision are highly dependent on data accuracy, predictor choice and modelling algorithm (Elith and Leathwick, 2009, Hijmans and Elith, 2014). Therefore, a few precautions are necessary: given that we used species presence data, we applied the modelling method which has proven most suitable for projects where absence data is missing (Phillips et al., 2009, Elith et al., 2011). Predictor choice was based on experts knowledge on species' ecology and in accordance with other publications investigating habitat and conservation management of fungi (Abrego et al., 2017, Mair et al., 2017, Jonsson 
et al., 2018). Given that Switzerland has several highly diverse biogeographic regions (Wohlgemuth, 1996), the nationwide scale suitably reflects various ecological niches.

Our study only considered species with a large data coverage for whole Switzerland (see methods). Therefore, rarely documented species were not considered in our approach, despite experts' knowledge on certain species' role as indicators for habitats or niches within floodplains such as Lyophyllum favrei, Amanita friabilis or Clitocybe barbularum (Delarze and Gonseth, 2015). Nevertheless, we argue that our results on abundant species might indicate a starting point for conservation measures for fungi in floodplains, which might be beneficial for rare species as well.

Future analyses including more information e.g. on forests and forest structure might refine the modelling approach (as e.g. for lichens in Switzerland, Dymytrova et al., 2016). Moreover, future models need to take into account forecasting to the future under climate change scenarios, especially as temperature has a high impact on the prediction of species' occurrence.

\section{Conclusion}

The dataset of SwissFungi proved valuable for defining riparian species in a standardized way. The species distribution modeling approach applied to macrofungi yielded important insights into conservation and management options for fungi. We showed that a majority of fungal species likely profit from river revitalizations given their affinity to the riparian habitat. Still, we argue that specific riparian specialist fungi and their individual niche requirements need to be considered in conservation planning and management strategies. The database information and the modelling approach provides a basis for future monitoring and conservation projects as well as for future field analyses for species with unclear ecology. 


\section{Acknowledgements}

We thank Stefan Blaser for an initial data search on SwissFungi. We are grateful to numerous volunteer mycologists for reporting their data to the SwissFungi database. Funding was provided by the Swiss Federal Offices for the Environment. We thank two anonymous reviewers and the editors Jacob Heilmann-Clausen and Lynne Boddy for helpful comments on a previous version of the manuscript. 


\section{References}

ABREGO, N., CHRISTENSEN, M., BAESSLER, C., AINSWORTH, A. M., HEILMANN CLAUSEN, J. \& B ̈̈̈SSLER, C. 2017. Understanding the distribution of woodinhabiting fungi in European beech reserves from species-specific habitat models. Fungal Ecology, 27, 168-174.

ABREGO N., NORBERG A., OVASKAINEN O., AERTS R. 2017. Measuring and predicting the influence of traits on the assembly processes of wood-inhabiting fungi Journal of Ecology 105:1070-1081

ACEVES-BUENO, E., ADELEYE, A. S., FERAUD, M., HUANG, Y., TAO, M., YANG, Y. \& ANDERSON, S. E. 2017. The Accuracy of Citizen Science Data: A Quantitative Review. The Bulletin of the Ecological Society of America, 98, 278-290.

AINSWORTH, A. M., DOUGLAS, B. \& SUZ, L. M. 2018. Big Blue Pinkgills formerly known as Entoloma bloxamii in Britain: E. bloxamii s. str., E. madidum, E. ochreoprunuloides forma hyacinthinum and E. tromadidum sp. nov. Field Mycology, 19, 5-14.

ANDREW, C., BÜNTGEN, U., EGLI, S., SENN- IRLET, B., GRYTNES, J.-A., HEILMANN- CLAUSEN, J., BODDY, L., BÄSSLER, C., GANGE, A., HEEGAARD, E., HØILAND, K., KIRK, P., KRISAI-GREILHUBER, I., KUYPER, T., KAUSERUD, H. 2019. Open-source data reveal how collections-based fungal diversity is sensitive to global change. Applications in Plant Sciences, 7, e01227$\mathrm{e} 01227$.

AUENBERATUNGSSTELLE, 2001-2008. Auendossier: Faktenblätter. Bundesamt für Umwelt, Bern.

BAUMGARTNER, M. 2009. Datenbank Ökomorphologie Stufe F. In: EIDGENÖSSISCHES DEPARTEMENT FÜR UMWELT, V., ENERGIE UND KOMMUNIKATION 
UVEK, BUNDESAMT FÜR UMWELT BAFU , ABTEILUNG WASSER (ed.). Bern.

BODDY, L., FRANKLAND, J. C. AND VAN WEST, P. (2008). Ecology of saprotrophic basidiomycetes. Amsterdam, Elsevier Academic Press. Vol. 28.

BOLLIGER, J., KIENAST, F. \& ZIMMERMANN, N. E. 2000. Risks of global warming on montane and subalpine forests in Switzerland ? A modeling study. Regional environmental change natural and social aspects, 1, 99-111.

BONNEY, R., COOPER, C., DICKINSON, J., KELLING, S., PHILLIPS, T., ROSENBERG, K. \& SHIRK, J. 2009. Citizen Science: A Developing Tool for Expanding Science Knowledge and Scientific Literacy. BioScience, 59, 977-984.

BREITENBACH, J. \& KRÄNZLIN, F. 1981-2005. Pilze der Schweiz : Beitrag zur Kenntnis der Pilzflora der Schweiz, Luzern, Verlag Mykologia.

BURNETT, J. H. 2003. Fungal populations and species, Oxford, Oxford University Press.

CAMATHIAS, L., BERGAMINI, A., KÜCHLER, M., STOFER, S. \& BALTENSWEILER, A. 2013. High-resolution remote sensing data improves models of species richness. Applied Vegetation Science, 16, 539-551.

CATFORD, J. \& JANSSON, R. 2014. Drowned, buried and carried away: effects of plant traits on the distribution of native and alien species in riparian ecosystems. New Phytologist, 204, 19-36.

D'AMEN, M., BOMBI, P., PEARMAN, P., SCHMATZ, D., ZIMMERMANN, N., DAMEN, M. \& BOLOGNA, M. 2011. Will climate change reduce the efficacy of protected areas for amphibian conservation in Italy? Biological Conservation, 144, 989-997.

DARBY, S. \& SEAR, D. 2008. River restoration : managing the uncertainty in restoring physical habitat, Chichester, West Sussex, Chichester, West Sussex : Wiley.

DELARZE, R. \& GONSETH, Y. 2015. Lebensräume der Schweiz : Ökologie, Gefährdung, Kennarten, Thun, Ott. 
DEVICTOR, V., WHITTAKER, R. \& BELTRAME, C. 2010. Beyond scarcity: citizen science programmes as useful tools for conservation biogeography. Diversity and Distributions, 16, 354-362.

DICKINSON, J., ZUCKERBERG, B. \& BONTER, D. 2010. Citizen Science as an Ecological Research Tool: Challenges and Benefits. Annual Review of Ecology, Evolution, and Systematics, Vol 41.

DYMYTROVA, L., STOFER, S., GINZLER, C., BREINER, F. \& SCHEIDEGGER, C. 2016. Forest-structure data improve distribution models of threatened habitat specialists: Implications for conservation of epiphytic lichens in forest landscapes. Biological Conservation, 196, 31-38.

ELITH, J., KEARNEY, M. \& PHILLIPS, S. 2010. The art of modelling range-shifting species. Methods in Ecology and Evolution, 1, 330-342.

ELITH, J. \& LEATHWICK, J. 2009. Species distribution models: ecological explanation and prediction across space and time. Annual Review of Ecology, Evolution, and Systematics 40, 677-697.

ELITH, J., PHILLIPS, S., HASTIE, T., DUDIK, M., CHEE, Y., DUDÍK, M. \& YATES, C. 2011. A statistical explanation of MaxEnt for ecologists. Diversity \& Distributions, $17,43-57$.

ELLENBERG, H. 2010. Vegetation Mitteleuropas mit den Alpen in ökologischer, dynamischer und historischer Sicht, Stuttgart, Ulmer.

ESRI 2015. ArcGIS Desktop: Release 10.2.2. CA: Environmental Systems Research Institute. FEDERAL OFFICE FOR THE ENVIRONMENT 2010. Bundesinventar der eidgenössischen Jagdbanngebiete. 
FEDERAL OFFICE FOR THE ENVIRONMENT 2011. Liste der National Prioritären Arten. Arten mit nationaler Priorität für die Erhaltung und Förderung, Stand 2011. Bern. Umwelt-Vollzug Nr. 1103.

FEDERAL OFFICE FOR THE ENVIRONMENT 2011. Convention on Wetlands of International Importance especially as Waterfowl Habitat, Volume 14583, Ramsar (Iran). Following UN treaty 1971.

FEDERAL OFFICE FOR THE ENVIRONMENT 2015. Verordnung über die Wasser- und Zugvogelreservate von internationaler und nationaler Bedeutung.

FEDERAL OFFICE FOR THE ENVIRONMENT 2017. Biodiversität in der Schweiz: Zustand und Entwicklung. Ergebnisse des Überwachungssystems im Bereich Biodiversität, Stand 2016, Bern.

FINK, S. \& SCHEIDEGGER, C. 2018. Effects of barriers on functional connectivity of riparian plant habitats under climate change. Ecological Engineering, 115, 75-90.

FINK, S. \& SENN-IRLET, B. 2016. Pilzvorkommen voraussagen. Wie weit helfen Modellierungen des Lebensraums? Schweizerische Zeitschrift für Pilzkunde, 94, 1214.

FRANKLIN, J. 2009. Mapping species distributions : spatial inference and prediction. Cambridge : Cambridge University Press.

GMINDER, A. 2010. Ständerpilze: Blätterpilze III, Stuttgart, Verlag Eugen Ulmer.

GROSS, A., BLASER, S. \& SENN-IRLET, B. J. 2019. SwissFungi: National data- and information center for the fungi of Switzerland [database]. Birmensdorf Swiss Federal Institute WSL.

GUISAN, A., TINGLEY, R., BAUMGARTNER, J., NAUJOKAITIS LEWIS, I., SUTCLIFFE, P., REGAN, T., BROTONS, L., MCDONALD MADDEN, E., MANTYKA PRINGLE, C., RHODES, J., MAGGINI, R., SETTERFIELD, S., ELITH, J., SCHWARTZ, M., WINTLE, B., BROENNIMANN, O., AUSTIN, M., 
FERRIER, S., KEARNEY, M., POSSINGHAM, H., BUCKLEY, Y., MARTIN, T. G. \& ARITA, H. 2013. Predicting species distributions for conservation decisions. Ecology Letters, 16, 1424-1435.

GUISAN, A. \& ZIMMERMANN, N. 2000. Predictive habitat distribution models in ecology. Ecological Modelling, 135, 147-186.

HIJMANS, R. J. \& ELITH, J. 2014. Species distribution modeling with R.

HIJMANS, R. J. \& VAN ETTEN, J. 2012. raster: Geographic analysis and modeling with raster data. $\mathrm{R}$ package version 2.0-12.

HIRZEL, A., RANDIN, C., GUISAN, A., LE LAY, G. \& HELFER, V. 2006. Evaluating the ability of habitat suitability models to predict species presences. Ecological Modelling, 199, 142-152.

IKEDA, D., GRADY, K., SHUSTER, S., WHITHAM, T. \& BOLDGIV, B. 2014. Incorporating climate change and exotic species into forecasts of riparian forest distribution. PLoS ONE, 9, e107037.

JONSSON, M., RATY, M., BARRING, L., MAIR, L., JÖNSSON, M., RÄTY, M., BÄRRING, L., STRANDBERG, G., LÄMÅS, T., SNÄLL, T. \& VISCONTI, P. 2018. Land use changes could modify future negative effects of climate change on oldgrowth forest indicator species. Diversity and Distributions, 24, 1416-1425.

KERR, J. 1997. Species Richness, Endemism, and the Choice of Areas for Conservation. Riqueza de Especies, Endemismo y Seleccion de Areas para Conservacion. Conservation Biology, 11, 1094-1100.

KLIMO, E. 2001. The floodplain forests in Europe : current situation and perspectives, Leiden, Brill.

KNUDSEN, H. \& VESTERHOLT, J. (eds.) 2008. Funga Nordica : agaricoid, boletoid and cyphelloid genera, Copenhagen: Nordsvamp. 
KRIEGLSTEINER, G. J. (ed.) 2000-2010. Die Grosspilze Baden-Württembergs. Band 1-4, Stuttgart: Ulmer.

KUMAR, L., SKIDMORE, A. \& KNOWLES, E. 1997. Modelling topographic variation in solar radiation in a GIS environment. International journal of geographical information science, 11, 475-497.

LAUBER, K., WAGNER G. \& GYGAX A. (2018). Flora Helvetica : illustrierte Flora der Schweiz: mit Artbeschreibungen und Verbreitungskarten von 3200 wild wachsenden Farn- und Blütenpflanzen, einschliessllich wichtiger Kulturpflanzen. Bern, Haupt Verlag.

LEHMANN, A., ALLENBACH, K., MAGGINI, R., RICHARD, J.-P., JACQUET, J.-M. \& DAO, H. 2010. Swiss environmental domains: a new spatial framework for reporting on the environment. Federal Office for the Environment FOEN, Environmental studies no. 1024, Bern.

LI, H.-Y., ZHAO, C.-A., LIU, C.-J. \& XU, X.-F. 2010. Endophytic fungi diversity of aquatic/riparian plants and their antifungal activity in vitro. The Journal of Microbiology, 48, 1-6.

LIU, C., WHITE, M., NEWELL, G. \& PEARSON, R. 2013. Selecting thresholds for the prediction of species occurrence with presence-only data. Journal of Biogeography, 40, 778-789.

MAIR, L., HARRISON, P., RATY, M., BARRING, L., STRANDBERG, G., RÄTY, M., BÄRRING, L. \& SNÄLL, T. 2017. Forest management could counteract distribution retractions forced by climate change. Ecological Applications, 27, 1485-1497.

MAIR, L., RÄTY, M., BÄRRING, L., STRANDBERG, G., LÄMÅS, T., SNÄLL, TORD, V. PIERO, JONSSON, M. 2018. Land use changes could modify future negative effects 
of climate change on old-growth forest indicator species Diversity and Distributions 24:1416-1425.

MANEL, S., WILLIAMS, H. C. \& ORMEROD, S. J. 2001. Evaluating presence-absence models in ecology: the need to account for prevalence. Journal of Applied Ecology, $38,921-931$.

MIHAL, I. \& BLANAR, D. 2014. Fungi and slime molds of alder and willow alluvial forests of the upper part of Muranka River (Central Slovakia). Folia Oecologia 41, 153-172.

MOSS, T. \& MONSTADT, J. 2008. Restoring Floodplains in Europe - Policy contexts and project Experiences, London, IWA Publishing.

NAIMAN, R. J., DÉCAMPS, N. \& MCCLAIN, M. E. 2005. Riparia: Ecology, conservation, and management of streamside communities. New York, Elsevier.

NILSSON, C., REIDY, C., DYNESIUS, M. \& REVENGA, C. 2005. Fragmentation and Flow Regulation of the World's Large River Systems. Science, 308, 405-408.

PHILLIPS, S., ANDERSON, R. \& SCHAPIRE, R. 2006. Maximum entropy modeling of species geographic distributions. Ecological Modelling, 190, 231-259.

PHILLIPS, S., DUDIK, M., ELITH, J., GRAHAM, C., LEHMANN, A., DUDÍK, M., LEATHWICK, J. \& FERRIER, S. 2009. Sample selection bias and presence-only distribution models: implications for background and pseudo-absence data. Ecological Applications, 19, 181-197.

PIOTROWSKI, J., LEKBERG, Y., HARNER, M., RAMSEY, P. \& RILLIG, M. 2008. Dynamics of mycorrhizae during development of riparian forests along an unregulated river. Ecography, 31, 245-253.

PURHONEN, J., HUHTINEN, S., KOTIRANTA, H., KOTIAHO, J. \& HALME, P. 2017. Detailed information on fruiting phenology provides new insights on wood-inhabiting fungal detection. Fungal Ecology, 27, 175-177. 
R CORE TEAM. 2016. R: A language and environment for statistical computing. $\mathrm{R}$ Foundation for Statistical Computing [Online]. Vienna, Austria. Available: http://www.R-project.org/

RICHARDSON, D., HOLMES, P., ESLER, K., GALATOWITSCH, S. \& STROMBERG, J. 2007. Riparian vegetation: degradation, alien plant invasions, and restoration prospects. Diversity \& Distributions, 13, 126-139.

SABO, J., SPONSELLER, R., DIXON, M., GADE, K., HARMS, T., HEFFERNAN, J., JANI, A., KATZ, G., SOYKAN, C., WATTS, J. \& WELTER, J. 2005. Riparian zones increase regional species richness by harbouring different, not more, species. Ecology, $86,56-62$.

SAKIO, H. \& TAMURA, T. (eds.) 2008. Ecology of riparian forests in Japan : disturbance, life history and regeneration. New York: Springer.

SCHATZ, A., KRAMER, A., DRAKE, J. 2017. Accuracy of climate-based forecasts of pathogen spread. Royal Society Open Science 4:160975-160975.

SCHNITZLER-LENOBLE, A. \& CARBIENER, R. 2007. Forêts alluviales d'Europe, Tec \& Doc.

SENN IRLET, B. 2012. Merkblatt Pilze: Karminschwärzling. Lyophyl-lum favrei R. Haller und R. Haller. www.wsl.ch/merkblaetter_pilze. Birmensdorf ZH: Eidg. Forschungsanstalt WSL.

SMITH, S. E. (2009). Mycorrhizal symbiosis. Read, D. (ed). Amsterdam, Academic. $3^{\text {rd }}$ edition

STOCKAN, J., BAIRD, J., LANGAN, S., YOUNG, M., IASON, G. \& LITTLEWOOD, N. 2014. Effects of riparian buffer strips on ground beetles (Coleoptera, Carabidae) within an agricultural landscape. Insect Conservation and Diversity, 7, 172-184.

TALLEY, S., COLEY, P. \& KURSAR, T. 2002. The effects of weather on fungal abundance and richness among 25 communities in the Intermountain West. BMC Ecology, 2, 7-7. 
TUKIAINEN, H., BAILEY, J., FIELD, R., KANGAS, K., HJORT, J. 2017. Combining geodiversity with climate and topography to account for threatened species richness Conservation Biology 31:364-375.

TULLOCH, A. I. T., CHADÈS, I. \& POSSINGHAM, H. 2013. Accounting for Complementarity to Maximize Monitoring Power for Species Management. Conservation Biology, 27, 988-999.

TURRINI, A. \& GIOVANNETTI, M. 2012. Arbuscular mycorrhizal fungi in national parks, nature reserves and protected areas worldwide: a strategic perspective for their in situ conservation. Mycorrhiza, 22, 81-97.

WELCH, B. L. 1947. The generalization of "Student's" problem when several different population variances are involved. Biomerika, 34, 28-35.

WELTEN, M., SUTTER, S. \& SCHWEIZERISCHEN NATURFORSCHENDEN GESELLSCHAFT, G. K. (eds.) 1982. Verbreitungsatlas der Farn- und Blütenpflanzen der Schweiz, Basel: Birkhäuser.

WICAKSONO, C., NOUHRA, E., RAES, N., AGUIRRE GUITERREZ, J., PASTOR, N., PACHECO, S., GEML, J. 2017. Contracting montane cloud forests: a case study of the Andean alder (Alnus acuminata) and associated fungi in the Yungas Biotropica 49:141-152.

WOHLGEMUTH, T. 1996. A biogeographical division of Switzerland based on a floristic approach. Botanica Helvetica, 106, 227-254.

WOLLAN, A., BAKKESTUEN, V., KAUSERUD, H., GULDEN, G., HALVORSEN, R. 2008. Modelling and predicting fungal distribution patterns using herbarium data Journal of Biogeography 35:2298-2310.

ZIMMERMANN, N. \& KIENAST, F. 1999. Predictive mapping of alpine grasslands in Switzerland: Species versus community approach. Journal of Vegetation Science, 10, 469-482. 


\section{Figures:}

Figure 1: Presence points of all riparian fungal species used for modelling (129) obtained from SwissFungi. Changes in elevation (relief based on the digital elevation model from 2019, obtained by Swisstopo) are shown in different shades of grey. Species' records in the database are not equally distributed across Switzerland, with a majority of species clustering in the area of the Central Plateau.

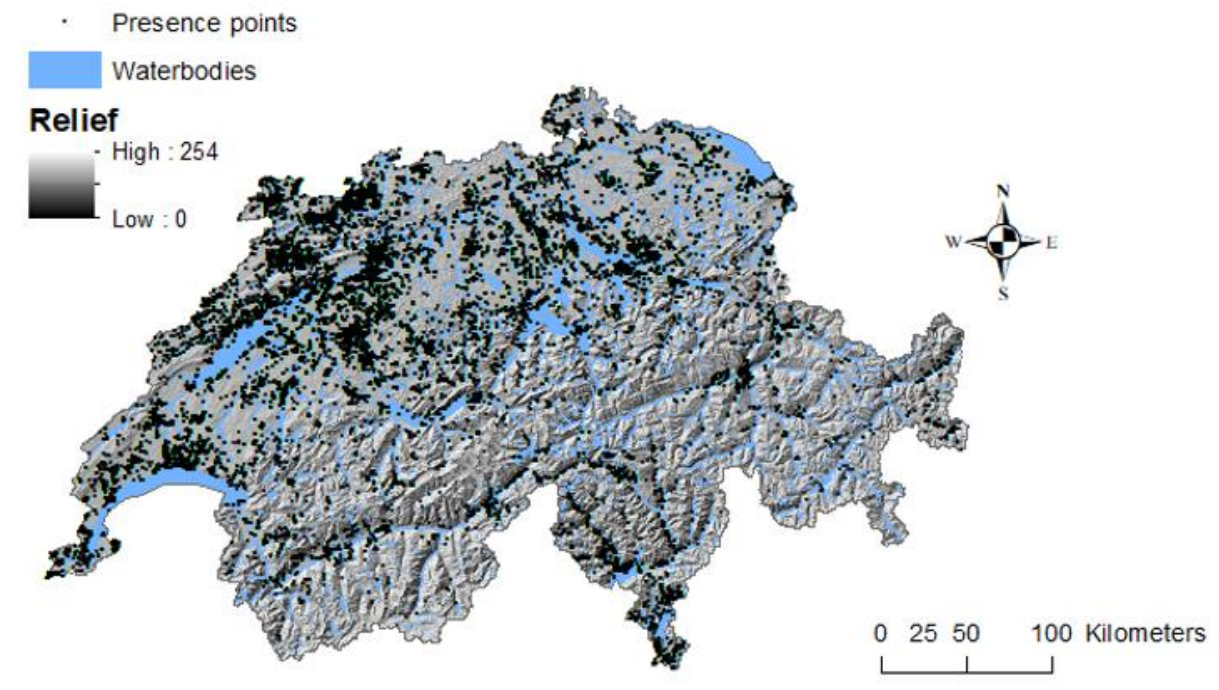


Figure 2: Predicted species distribution of all fungal species in Switzerland. Protected areas are marked with brown lines. The regions with many predicted species $(>60)$ both inside and outside protected areas are in the Central Plateau, Jura and Ticino.

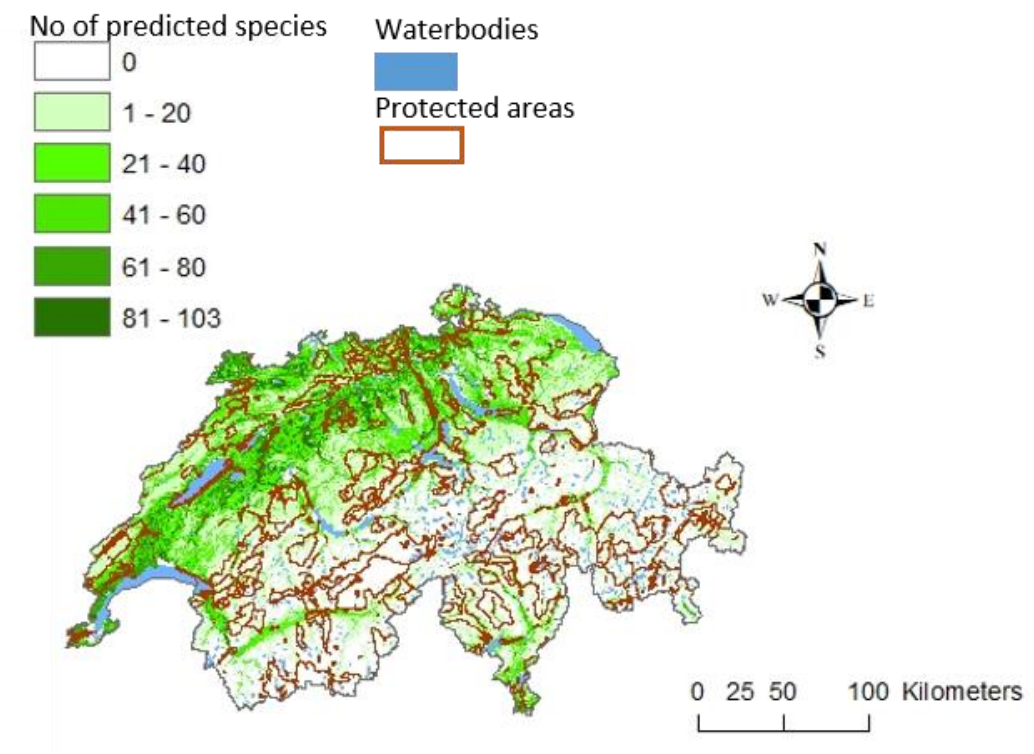


Figure 3: Local variation between predicted species distribution for various functional groups shown for the Ticino catchment: A) ectomycorrhizal (12 species), B) plant parasitic(2), C) saprobic soil (20), D) saprobic dead wood (60) and E) other saprobic species (9).
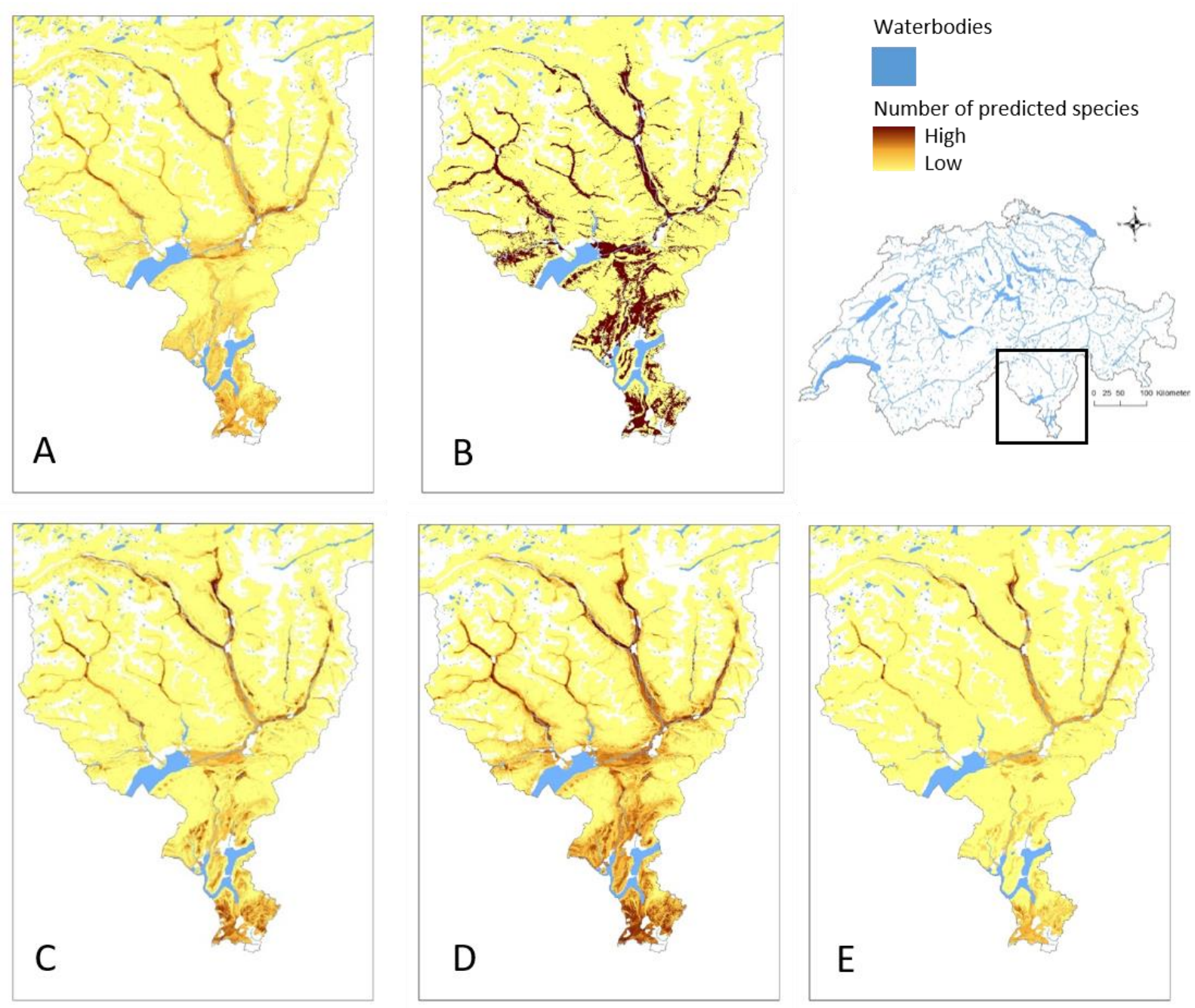
Table 1: Environmental predictor layers and layers of areas under protection or management restriction

\begin{tabular}{|c|c|}
\hline Predictors & References \\
\hline \multicolumn{2}{|l|}{ Geological predictors } \\
\hline Calcareous content of the bedrock and surface & Lehmann et al., 2010 \\
\hline Soil permeability & Camathias et al., 2013 \\
\hline Water-holding capacity & Camathias et al., 2013 \\
\hline Hydrometric properties & Camathias et al., 2013 \\
\hline Stone content & Camathias et al., 2013 \\
\hline \multicolumn{2}{|l|}{ Topographic predictors* } \\
\hline Wetness index & $\begin{array}{l}\text { Following Tarboton 1997, see in Camathias } \\
\text { et al., } 2013\end{array}$ \\
\hline Topographic index & Camathias et al., 2013 \\
\hline Slope & Camathias et al., 2013 \\
\hline \multicolumn{2}{|l|}{ Climatic predictors } \\
\hline Mean annual temperature & Zimmermann and Kienast, 1999 \\
\hline Mean annual precipitation & Zimmermann and Kienast, 1999 \\
\hline Mean annual number of summer precipitation days & Zimmermann and Kienast, 1999 \\
\hline Annual global potential shortwave radiation & Algorithm following Kumar et al., 1997 \\
\hline Mean Monthly direct shortwave radiation & $\begin{array}{l}\text { Following Tarboton 1997, see in Camathias } \\
\text { et al., } 2013\end{array}$ \\
\hline Mean annual number of frost days during the growing & Bolliger et al., 2000 \\
\hline Average site water balance & $\begin{array}{l}\text { Following Tarboton 1997, see in Camathias } \\
\text { et al., } 2013\end{array}$ \\
\hline \multicolumn{2}{|l|}{ Protected areas } \\
\hline Floodplains of national importance & Auenberatungsstelle 2001-2008 \\
\hline Biosphere areas & Federal Office for the Environment 2012 \\
\hline Landscapes and natural monuments of national & Federal Office for the Environment 2010 \\
\hline Emerald areas & Federal Office for the Environment 2010 \\
\hline Fens of national importance & Federal Office for the Environment 2017 \\
\hline Reserves for waterbirds and migratory birds of & Federal Office for the Environment 2015 \\
\hline Dry grasslands of national importance & Federal Office for the Environment 2017 \\
\hline Swiss game reserves & Federal Office for the Environment 2010 \\
\hline Ramsar areas & Federal Office for the Environment 2011 \\
\hline Parc of national importance & Federal Office for the Environment 2012 \\
\hline
\end{tabular}


Table 2: Results of quasilikelihood models testing for the influence of functional groups and protection status on actual (above) and predicted (below) presence of fungal species.

Significant p-values are shown in bold.

Actual predicted presence

\section{Functional group}

ectomycorrhiza

plant parasites

other saprobes

soil saprobes

dead wood saprobes

\begin{tabular}{rrrrrrr}
\multicolumn{3}{c}{ protected overall } & \multicolumn{3}{c}{ protected high } & \multicolumn{3}{c}{ protected low } \\
$\mathbf{n}$ & t value & $\mathbf{p}$ & t value & $\mathbf{p}$ & t value & $\mathbf{p}$ \\
12 & 5.134 & $<\mathbf{0 . 0 0 1}$ & 6.314 & $<\mathbf{0 . 0 0 1}$ & 2.163 & $\mathbf{0 . 0 3 3}$ \\
2 & -0.295 & 0.769 & -0.202 & 0.841 & -1.487 & 0.140 \\
9 & -1.751 & 0.083 & -1.683 & 0.095 & -1.483 & 0.141 \\
20 & -3.076 & $\mathbf{0 . 0 0 3}$ & -3.214 & $\mathbf{0 . 0 0 2}$ & -2.328 & $\mathbf{0 . 0 2 2}$ \\
61 & -2.598 & $\mathbf{0 . 0 1 1}$ & -2.357 & $\mathbf{0 . 0 2 0}$ & -3.300 & $\mathbf{0 . 0 0 1}$
\end{tabular}

Predicted presence

Functional group
ectomycorrhiza
plant parasites
other saprobes
soil saprobes
dead wood saprobes

protected overall

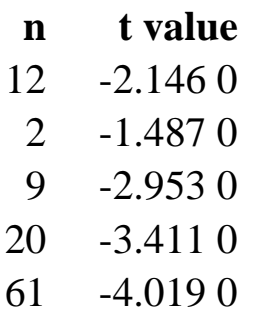

$\mathbf{p}$

0.140

0.004

0.001

$\mathbf{0 . 0 0 0}$ protected high p t value $-9.8152$

$$
-0.592
$$

$-1.450$

$-1.234$

$-1.582$ protected low

$\begin{array}{rrr}\mathbf{p} & \text { t value } & \mathbf{p} \\ <\mathbf{0 . 0 0 1} & -18.481 & <\mathbf{0 . 0 0 1} \\ 0.555 & -0.490 & 0.625 \\ 0.150 & -1.088 & 0.279 \\ 0.220 & -1.650 & 0.102 \\ 0.117 & -1.825 & 0.071\end{array}$

